\title{
PENERAPAN PENDEKATAN KONTEKSTUAL MENGGUNAKAN MEDIA GAMBAR BINATANG UNTUK MENINGKATKAN KETERAMPILAN MENDESKRIPSI SECARA TERTULIS SISWA KELAS II SDN PUNIK
}

\author{
Bq. Murtiah \\ Kepala SDN Punik Praya, murtiahbq@gmail.com
}

\begin{abstract}
INFO ARTIKEL
Riwayat Artikel:

Diterima: 06-03-2018

Disetujui: 16-04-2018

\section{Kata Kunci:}

Pendekatan Kontekstual, Media Gambar
\end{abstract}

Keterampilan

Mendeskripsi Tertulis.

\section{A. LATAR BELAKANG}

Bahasa memiliki peran penting dalam perkembangan intelektual, sosial, dan emosional peserta didik dalam mempelajari semua bidang studi (BSNP, 2006). Untuk berbahasa dengan baik dan benar, maka diperlukan pendidikan dan pembelajaran bahasa Indonesia. Pendidikan dan pembelajaran bahasa Indonesia merupakan salah satu aspek penting yang perlu diajarkan kepada siswa di sekolah. Oleh karena itu pemerintah membuat kurikulum bahasa Indonesia yang wajib untuk diajarkan kepada siswa pada setiap jenjang pendidikan, yakni dari tingkat Sekolah Dasar (SD) sampai dengan Perguruan Tinggi (PT).

Pembelajaran bahasa Indonesia merupakan suatu tantangan tersendiri bagi seorang guru, mengingat bahasa ini merupakan bahasa pengantar yang dipakai untuk menyampaikan materi pelajaran. Pembelajaran bahasa Indonesia berfungsi membantu peserta didik untuk mengemukakan gagasan dan perasaan, berpartisipasi dalam masyarakat dengan menggunakan bahasa tersebut, dan menemukan serta menggunakan kemampuan analitis dan imajinatif (Depdiknas, 2006).

Sesuai dengan kenyataan yang terjadi pada saat ini, mata pelajaran bahasa Indonesia sering diremehkan oleh sebagian besar siswa, bahkan dianggap sebagai mata pelajaran yang membosankan, khususnya dalam aspek menulis. Menurut Johana Pantow dkk (2002) yang tersedia dalam situs http://digilib.itb.ac.id yang diakses pada tanggal 26 Januari 2008, menyatakan bahwa dalam dunia pendidikan, menulis merupakan suatu tuntutan keterampilan yang harus dikuasai oleh manusia sebagai bahasa tulis. Oleh karena itu, sejak dini pengajaran bahasa selalu harus didasarkan pada keterampilan bahasa dan salah satunya adalah menulis.

Di SDN Punik Lombok Tengah kesulitan siswa dalam menulis biasanya terlihat ketika siswa diminta untuk menulis sebuah karangan sederhana, mendeskripsikan suatu benda ataupun ketika menulis puisi, mereka sering mengeluh dan terlihat bingung dengan apa yang ingin mereka tulis. Kebosanan, kejenuhan, serta kebingungan siswa dalam hal menulis yang mengakibatkan rendahnya prestasi belajar siswa dalam pembelajaran menulis dapat disebabkan oleh beberapa faktor, antara lain :

1. Kurangnya minat siswa terhadap kegiatan menulis.

2. Kurangnya motivasi siswa, baik dari dalam diri mereka maupun dari lingkungan belajar.

3. Pengembangan strategi pembelajaran yang kurang membangkitkan daya imajinasi siswa dan kreativitas siswa dalam berbahasa maupun bersastra. 
4. Media yang digunakan dalam pembelajaran yang kurang sesuai sehingga siswa kurang bersemangat dalam belajar.

Masalah yang terjadi pada siswa kelas II SDN Punik Lombok Tengah adalah kurangnya pemahaman siswa terhadap cara mendeskripsikan suatu benda. Hal itu dapat diketahui dari hasil tes pada mata pelajaran Bahasa Indonesia aspek menulis pada tanggal 15 Januari 2008, dengan tujuan pembelajaran mendeskripsikan binatang dengan bahasa tulis yang dilaksanakan pada siswa kelas II SDN Punik Lombok Tengah, yang dirasakan masih kurang. Dari tes tersebut diperoleh hasil tulisan siswa belum sempurna, karena penggunaan katanya belum tepat dan kalimatnya cenderung diulangulang sehingga tidak mudah untuk dipahami. Perolehan nilai rata-rata kelas yang seharusnya mencapai nilai di atas nilai Kriteria Ketuntasan Minimal (KKM) kelas II SDN Punik Lombok Tengah mata pelajaran Bahasa Indonesia aspek menulis, yakni 70 dan pada kenyataannya hanya mencapai angka 65, sehingga hanya 27\% siswa yang memenuhi Kriteria Ketuntasan Minimal (KKM) bahasa Indonesia dalam aspek menulis untuk kelas II semester II SDN Punik Lombok Tengah. Dengan adanya permasalahan yang telah diuraikan di atas, maka guru harus mengambil tindakan, yakni dengan mencari dan menggunakan suatu pendekatan atau model pembelajaran yang efektif, inovatif, dan berpotensi memperbaiki pembelajaran menulis, sehingga meningkatkan minat, motivasi, dan sikap siswa terhadap pembelajaran menulis yang berakibat pada meningkatnya prestasi belajar siswa. Untuk itulah guru (peneliti) merancang suatu bentuk pembelajaran yang aktif, kreatif, efektif, dan menyenangkan melalui pendekatan kontekstual dengan media gambar sebagai media alternatif untuk memperbaiki pembelajaran menulis.

Pendekatan kontekstual (Contextual Teaching and Learning) merupakan konsep belajar yang membantu guru mengaitkan antara materi yang diajarkannya dengan situasi dunia nyata siswa dan mendorong siswa membuat hubungan antara pengetahuan yang dimilikinya dengan penerapannya dalam kehidupan mereka sebagai anggota keluarga dan masyarakat (Dikdasmen Diknas, 2002:1). Media gambar dimaksudkan untuk memudahkan siswa dalam mendeskripsikan seekor binatang dengan bahasa tulis. Media gambar digunakan dalam penelitian ini karena pola berpikir siswa kelas II yang masih memerlukan media pembelajaran yang konkrit. Dengan kedua hal tersebut diharapkan dapat meningkatkan keterampilan siswa kelas II SDN Punik Lombok Tengah dalam mendeskripsikan binatang dengan bahasa tulis.

Berdasarkan latar belakang yang telah diuraiakn di atas, maka penelitian ini akan berfokus pada hal-hal yang berkaitan dengan upaya medayagunakan media gambar binatang sebagai sarana pembelajaran berbasis kontekstual sehingga dapat meningkatkan keterampilan siswa kelas II SDN Punik Lombok Tengah dalam mendeskripsi secara tertulis.

\section{B. METODE PENELITIAN}

\section{Pendekatan}

Jenis penelitian ini adalah penelitian tindakan kelas dengan pendekatan analisis kualitatif yang bertujuan untuk meningkatkan kemampuan dan keterampilan mendeskripsi secara tertulis pada mata pelajaran Bahasa Indonesia siswa kelas II SDN Punik Lombok Tengah. Proses pelaksanaannya bersifat kolaboratif dengan tim yaitu guru kelas IV dan guru kelas I. adapun langkahlangkah penelitian ini mengikuti prinsip-prinsip dasar dalam penelitian tindakan seperti yang digambarkan oleh Kurt Lewin (dalam Zainal Aqib, 2006:22) sebagai langkah spiral atau daur ulang perencanaan, pelaksanaan tindakan, pengamatan/observasi, dan refleksi yang mungkin diikuti dengan perencanaan tindakan berikutnya.

Dalam penelitian ini peneliti (guru) melaksanakan tindakan hingga tiga siklus. Adapun langkah-langkah dari tiap siklusnya adalah sebagai berikut:

Tindakan pada siklus I dilakukan melalui pendekatan kontekstual dengan memanfaatkan media gambar binatang sebagai media pembelajaran.

a. Perencanaan Tindakan

1) Siswa diharapkan dapat mendeskripsikan seekor binatang

2) Siswa diharapkan dapat mendeskripsikan binatang secara tertulis

3) Siswa diharapkan dapat menuliskan deskripsinya terhadap seekor binatang dengan kalimat yang tepat dalam penggunaan katanya.

Guru sebagai peneliti menyusun:
a) Rencana Pembelajaran
b) Media gambar binatang
c) Membuat soal tes kemampuan
d) Melaksanakan evaluasi tindakan

b. Pelaksanaan Tindakan

Tindakan I dilaksanakan oleh peneliti (guru) dibantu oleh guru lain yang telah ditunjuk sebagai tim penelitian. Pada akhir pembelajaran dilaksanakan tes untuk mengevaluasi tindakan I ini. Hasil pekerjaan siswa dievaluasi dan membuat catatan lapangan tentang kesulitan atau kesalahankesalahan siswa dalam mendeskripsi binatang secara tertulis, serta memikirkan cara mengatasinya. c. Observasi Tindakan

Selama pembelajaran berlangsung aktivitas siswa diamati oleh guru sebagai peneliti, sedangkan aktivitas guru diamati oleh guru lain yang termasuk dalam tim penelitian dengan menggunakan lembar observasi.

\section{d. Refleksi Tindakan}

Semua data yang diperoleh akan dideskripsikan, baik data hasil evaluasi maupun hasil observasi. 
Berdasarkan hasil pengamatan tersebut diambil kesimpulan apakah siswa sudah terampil dalam mendeskripsi secara tertulis atau belum. Berdasarkan hasil analisis data tersebut kemudian disimpulkan apakah pemberian tindakan perlu diulangi atau tidak. Jika tindakan perlu diulangi, maka peneliti bersama tim merancang kembali tindakan yang akan dilaksanakan pada siklus berikutnya. Jika tujuan masih belum tercapai maka perlu diberikan tindakan lanjutan, sehingga pada siklus ini subyek penelitian benar-benar mencapai tujuan pembelajaran yang diharapkan.

\section{Teknik atau Prosedur Pengumpulan Data}

a. Tes

Teknik tes ini digunakan untuk mengumpulkan data hasil tes pada setiap akhir tindakan, untuk memperoleh data tentang pemahaman siswa terhadap materi pelajran yang telah dipelajari. Tes ini digunakan untuk mengetahui keberhasilan siswa dalam kegiatan pembelajaran yang telah diikutinya. Hasil tes tersebut dipakai sebagai acuan untuk (1) melihat kemajuan siswa dalam mengikuti program pembelajaran, (2) analisis dan refleksi untuk tidakan berikutnya. Hasil pekerjaan siswa diperiksa dan dianalisis untuk menentukan letak kesalahan atau kekurangan siswa dalam menyelesaikan tugas dalam mendeskripsi secara tertulis.

b. Observasi

Teknik observasi digunakan untuk mengamati aktivitas guru dan murid. Obesrvasi ini bertujuan untuk (1) mengetahui kesesuaian pelaksanaan tindakan dengan perencanaan tindakan, (2) mengetahui seberapa jauh pelaksanaan tindakan yang sedang berlangsung dapat menghasilkan perubahan yang dikehenndaki. Dalam pelaksanaan observasi digunakan lembar onservasi. Observasi dilakukan oleh tiga orang observer termasuk guru pada saat pembelajaran berlangsung. Aspek yang diamati adalah aktivitas siswa selama pembelajaran berlangsung yang diamati oleh guru sebagai peneliti dan keterampilan mengajar guru yang diamati oleh guru lain sebagai anggota tim.

\section{Analisis Data}

Analisis data dilakukan selama dan sesudah pengumpulan data. Berdasarkan dari lembar jawaban dan lembar observasi aktivitas siswa dan keterampilan guru dalam pembelajaran kemudian diadakan analisis.

Semua data dikaji dan dibahas bersama antara peneliti dengan teman sejawat, selanjutnya ditindaklanjuti dengan mengadakan refleksi yang merupakan kegiatan analisis, sintesis, dan interpretsi terhadap semua informasi yang diperoleh dari penelitian tindakan untuk ditarik suatu kesimpulan. Penarikan kesimpulan/verivikasi data berfungsi untuk meyakinkan bahwa data yang diperoleh telah memenuhi syarat data yang baik. Untuk data yang berupa ungkapan-ungkapan/pernyataan-pernyataan menggunakan analisis logik, sedangkan data tes menggunakan analisis deskriptif.

Kriteria penilaian yang digunakan untuk menunjukkan penguasaan kemampuan yang tarafnya dapat diklasifikasikan dalam tabel berikut:

TABEL 1.

TARAF PENGUASAAN KEMAMPUAN

\begin{tabular}{|c|c|c|}
\hline $\mathrm{NO}$ & $\begin{array}{c}\text { TARAF PENGUASAAN } \\
\text { KEMAMPUAN (\%) }\end{array}$ & KATEGORI \\
\hline 1. & $85 \%$...................... $100 \%$ & Sangat baik \\
\hline 2. & $70 \% \ldots \ldots \ldots \ldots \ldots \ldots . . . \quad 84 \%$ & Baik \\
\hline 3. & $55 \%$ & Sedang \\
\hline 4 . & $40 \% \ldots \ldots \ldots \ldots \ldots \ldots \ldots . . \quad 54 \%$ & Kurang \\
\hline 5. & o \% ….................... $39 \%$ & Sangat kurang \\
\hline
\end{tabular}

Untuk menganalisis data hasil observasi terhadap partisipasi aktif siswa dapat dilakukan dengan cara:

a. Aktivitas siswa dalam kelompok

Selama pelaksanaan tindakan, 22 siswa dibagi menjadi 6 kelompok. Guru, dalam hal ini sebagai peneliti melaksanakan pem-belajaran dibantu oleh teman sejawat sebagai observer yang mengobservasi 6 kelompok siswa tersebut.

Adapun cara pengamatannya menggunakan lembar observasi yang telah disiapkan yang terdapat pada lampiran. Sedangkan kategori untuk aktivitas siswa taraf penguasaan kemampuan mengacu pada tabel 3 .

Aspek aktivitas siswa dalam kelompok yang diamati dalam penelitian tindakan ini adalah (1) keterlibatan siswa dalam pembelajaran, (2) keaktifan siswa dalam kelompoknya, (3) keaktifan siswa dalam melaksanakan tugas dari guru, (4) keberanian siswa dalam membacakan hasil karyanya, (5) kerjasama siswa dalam kelompok, (6) sikap bersahabat siswa terhadap dengan anggota kelompok, (7) respon siswa dalam pembelajaran dengan menunjukkan keceriaan dan antusiasme.

b. Aktivitas siswa dalam kelas

Penilaian terhadap aktivitas siswa di dalam kelas hampir sama dengan penilaian terhadap aktivitas siswa dalam kelompok. kategori dan prosentase yang digunakan sama. Adapun aspek yang diamati adalah (1) keterlibatan siswa dalam pembelajaran (bertanya dan menjawab pertanyaan), (2) keaktifan siswa dalam melaksanakan tugas dari guru, (3) keberanian siswa dalam menyampaikan hasil karyanya, (4) menampilkan sikap bersahabat terhadap temantemannya, (5) respon siswa dalam pembelajaran dengan menunjukkan keceriaan dan antusiasmenya selama pembelajaran. 
C. HASIL DAN PEMBAHASAN

1. Deskripsi Hasil Penelitian Siklus I

a. Perencanaan Tindakan I

Perencanaan tindakan pembelajaran

dikembangkan berdasarkan hasil studi pendahuluan. Peneliti menyusun rencana pembelajaran kontekstual untuk meningkatkan keterampilan mendeskripsi secara tertulis. Rencana pembelajaran ini digunakan sebagai petunjuk dan pegangan guru mengenai langkah yang harus dilakukan agar pelaksanaan pembelajaran berjalan dengan efektif dan efisien. Dalam rencana pembelajaran tertuliskan mengenai kompetensi dasar yang harus dicapai, indikator pembelajaran, materi/tema masalah, alokasi waktu dan jenis evaluasi untuk memperoleh umpan balik.

Pada siklus I ini kegiatan yang direncanakan untuk dilaksanakan adalah :

1) Pembelajaran menulis untuk mendeskripsikan sebuah objek dengan tema "Binatang di sekitarku".

2) Pembelajaran menggunakan media gambar binatang "Sapi" yang dibuat besar untuk ditempel di papan tulis sebagai media untuk mendeskripsi.

3) Menerapkan konsep penggunaan kata yang benar, tepat dan sesuai proporsi dalam setiap kalimat deskripsi.

4) Mengadakan evaluasi pada akhir tahapan tindakan I.

\section{b. Observasi dan Hasil Pelaksanaan Tindakan I}

Pada tahap observasi tindakan I ini, peneliti (guru) bersama tim peneliti melakukan observasi terhadap aktivitas pembelajaran di kelas II dengan lembar observasi yang telah disediakan. Dalam melakukan observasi, hal pokok yang diamati adalah aktivitas siswa dan keterampilan guru selama proses pembelajaran berlangsung. Kegiatan dalam proses pembelajaran dilihat dari rencana pembelajaran maupun kegiatan pembelajaran di kelas, meliputi:

\section{a. Keaktifan Siswa di Kelas}

Keterlibatan siswa dalam kegiatan pembelajaran (bertanya jawab) sangat kurang, karena hanya $27,2 \%$ siswa yang aktif dalam pembelajaran.

1) Aktivitas siswa dalam mengerjakan tugas dari guru sangat baik, hal itu terlihat dari data hasil observasi yang menyatakan bahwa dari 22 siswa hanya 1 siswa yang kurang aktif dalam pembelajaran.

2) Kemauan dan keberanian siswa untuk membacakan karyanya di depan kelas dapat dikatakan baik, karena 82 \% siswa berani dan mau membacakan karyannya di depan kelas.

3) Interaksi siswa dengan siswa lain masih sangat kurang, karena hanya $14 \%$ siswa yang mampu menampilkan sikap bersahabat terhadap temantemannya.

4) Respon siswa dalam pembelajaran masih sangat kurang, karena menurut data yang diperoleh dari 22 siswa hanya ada 9 siswa yang respon terhadap pembelajaran dengan menunjukkan keceriaan dan antusiasmenya saat pembelajaran.

\section{b. Hasil Belajar Siswa}

i. Secara prosentase keterampilan mendeskripsi secara tertulis siswa kelas II pada tindakan siklus I masih kurang yaitu $45,5 \%$

2) Dari 22 siswa yang meiliki keterampilan mendeskripsi secara tertulis dengan sangat baik ada 1 siswa (4\%), memiliki keterampilan baik ada 9 siswa (41\%), berketerampilan sedang ada 10 siswa (45\%), berketerampilan mendeskripsi secara tertulis kurang ada 2 siswa (9\%).

3) Secara umum hampir sebagian siswa belum terampil dalam mendeskripsi secara tertulis.

4) Hampir sebagian siswa belum terampil dalam menulis dengan menggunakan pemilihan kata yang tepat dan tulisan yang rapi.

\section{c. Analisis dan Refleksi Tindakan I}

a. Proses Pembelajaran

1) Dalam pengembangan pembelajaran, pembagian waktu masih kurang tepat pada akhir pelajaran agak tergesagesa, karena kehabisan waktu. Oleh karena itu untuk pertemuan berikutnya perlu direncanakan kembali dengan tepat dan cermat sehingga tidak ada perlambatan ataupun percepatan waktu.

2) Dalam pembelajaran, pendekatan yang digunakan sebagai alternatif pembelajaran belum jelas terlihat karena belum adanya kelompok belajar. Oleh karena itu dalam siklus berikutnya guru harus membuat rencana pembelajaran yang menonjolkan aktivitas pembelajaran kontekstual, khususnya dengan adanya kelompok belajar dalam pembelajaran. 
3) Interaksi guru dengan siswa masih perlu diperbaiki karena perhatian yang diberikan oleh guru belum merata, pemberian umpan balik belum bervariasi dan motivasi guru kepada siswa masih perlu ditingkatkan.

4) Selama pembelajaran berlangsung masih jarang siswa yang respon terhadap pembelajaran, hal itu ditunjukkan dari beberapa sikap siswa yang acuh ketika pembelajaran berlangsung.

5) Dalam proses pembelajaran mendeskripsi secara tertulis yang baik dan benar, guru (peneliti) sudah berusaha optimal dengan memanfaatkan gambar binatang yang menarik sehingga imajinasi siswa dalam mendeskripsi seekor binatang dapat tertuang secara nyata.

\section{b. Hasil Pembelajaran}

Setelah pembelajaran mendeskripsi secara tertulis melalui pembelajaran kontekstual dengan menggunakan gambar binatang pada siswa siswa kelas II berlangsung, dari hasil pembelajaran khusunya keterampilan mendeskripsi secara tertulis mengalami peningkatan hampir dua kali lipat dengan studi pendahuluan atau sebelum diadakan tidakan I. secara prosentase keterampilan mendeskripsi secara tertulis siswa kelas II sebesar 27\%, dan setelah dilaksanakan pembelajaran atau tindakan I prosentasenya naik atau meningkat menjadi $45,4 \%$. Untuk meningkatkan hasil belajar siswa atau keterampilan mendeskripsi secara tertulis pada siswa kelas II sangat diperlukan kesabaran, keuletan, kecermatan dan kebersamaan jiwa seorang guru dengan berbagai metode, strategi, dan media pembelajaran serta pemberian informasi yang benar secara komunikatif dan kondusif.

\section{Deskripsi Hasil Penelitian Siklus II a. Proses Pembelajaran}

1) Tujuan Pembelajaran

Tujuan pembelajaran yang dirumuskan sudah spesifik sesuai dengan tingkat usia dan kemampuan siswa serta sesuai dengan materi pembelajaran.

2) Pengembangan Pelajaran

Pengembangan pelajaran logis, pembagian waktu lebih cermat dan guru banyak memberi kesempatan kepada siswa untuk bertanya, berlatih, dan berpartisipasi aktif.
3) Penguasaan guru terhadap materi pelajaran

Guru menguasai materi dan tingkat kemudahan menyampaikan materi cukup memadai karena lebih dari $55 \%$ siswa sudah terampil dalam mendeskripsi secara tertulis.

4) Pengelolaan Belajar

Pengunaan waktu sudah efektif, pengelolaan kelas lancar dan tingkat kedisiplinan siswa cukup memadai tetapi masih ada beberapa siswa yang perhatiannya tidak tertuju pada pembelajaran yang sedang berlangsung.

5) Interaksi guru dengan kelompok belajar Guru cukup aktif dalam membimbing siswa dan memberikan motivasi-motivasi kepada siswa dalam kelompok, sehingga kegiatan dalam kelompok tidak pasif atau macet.

6) Interaksi guru dengan masing-masing siswa Perhatian guru selalu tertuju pada siswa namun masih belum merata, pemberian umpan balik cukup baik dan bervariasi yaitu berupa ucapan (sanjungan), anggukan dan senyuman..

7) Interaksi antar siswa

a) Pembelajaran secara berkelompok sudah menunujukkan aktifitas masing-masing kelompoknya, namun ada beberapa siswa dalam kelompok yang belum begitu respon dengan apa yang harus dikerjakan bersama kelompoknya.

b) Guru sering tampak berkeliling secara merata kepada setiap kelompok dengan sesekali memberikan pengarahan, sehingga antar siswa selalu terjadi komunikasi.

\section{b. Hasil Belajar Siswa}

Secara prosentase keterampilan mendeskripsi secara tertulis siswa kelas II pada tindakan siklus II mengalami peningkatan yaitu $59 \%$.

1) Dari 22 siswa yang memiliki keterampilan mendeskripsi secara tertulis dengan sangat baik ada 1 siswa (4\%), memiliki keterampilan baik ada 12 siswa (55\%), berketerampilan sedang ada 9 siswa (41\%).

2) Secara umum hampir sebagian siswa sudah mulai terlihat terampil dalam mendeskripsi secara tertulis.

3) Hampir sebagian siswa sudah mulai terampil dalam menulis dengan menggunakan pemilihan kata yang tepat dan tulisan yang rapi.

4) Melalui pembelajaran kontekstual dengan mendayagunakan puzzle (potongan gambar) binatang dapat meningkatkan keterampilan siswa dalam mendeskripsi secara tertulis, semangat siswa, daya 
imajinasi siswa dan partisipasi aktif siswa dalam kelompok dan antar siswa di dalam proses pembelajaran.

\section{c. Analisis dan Refleksi Tindakan II}

Proses pembelajaran pada siklus II ini sudah lebih baik dari pada pembelajaran pada siklus I. Hal ini terbukti dengan adanya peningkatan aktivitas proses pembelajaran baik oleh guru ataupun oleh siswa. Ada beberapa hal yang masih perlu diperbaiki antara lain:

1) Penggunaan media pembelajaran harus lebih variatif lagi untuk meningkatkan daya imajinasi siswa sehingga siswa dapat mendeskripsi binatang dengan baik.

2) Pemberian motivasi atau rangsangan harus lebih ditingkatkan lagi, supaya siswa lebih terlihat antusiasmenya dengan menunjukkan keceriaannya saat pembelajaran berlangsung.

Prosentase hasil kemampuan atau keterampilan mendeskripsi secara tertulis pada siklus II sebesar 59\% sedang pada siklus I sebesar 45,4\% menunjukkan adanya peningkatan sebesar $13,5 \%$, yakni dari kategori kurang menjadi kategori sedang. Maka siklus II perlu ditindaklanjuti pada siklus III untuk dapat mencapai hasil dengan kategori baik serta dengan tingkat keterampilan mendeskripsi secara tertulis yang lebih tinggi.

\section{a. Deskripsi Hasil Penelitian Siklus III Proses Pembelajaran}

1) Tujuan Pembelajaran

Tujuan yang dirumuskan sudah jelas sesuai dengan tingkat usia dan kemampuan siswa serta berkaitan langsung dengan materi pelajaran dan kemampuan anak.

2) Pengembangan Pelajaran

Pengembangan pelajaran logis, kemajuan terhadap konsisten pembagian waktu tepatdan memberikan banyak kesempatan pada siswa untuk berpartisipasi aktif secara langsung.

3) Penguasaan Guru terhadap Materi Pelajaran Guru sangat menguasai materi yang diajarkan dan penjabarannya memadai dan komunikatif sehingga sangat mudah dimengerti oleh siswa.

4) Pengelolaan Belajar

Penggunaan waktu dalam pengelolaan belajar sudah dapat dikatakan efektif, kreatif, dan bervariasi sehingga siswa terlihat sangat antusias dalam kegiatan mendeskripsi secara tertulis.

5) Interaksi Guru dengan kelompok Belajar Guru lebih aktif mengembangkan tingkat kemampuan dan pemahaman siswa melalui permainan dan kerjasama dalam kelompok belajar. Selain itu guru juga sering berkeliling atau sangat responsif untuk selalu berusaha memberi motivasi kepada siswa untuk aktif dan kreatif sehingga kerja kelompok benarbenar lebih hidup.

6) Interaksi Guru dengan Masing-masing Siswa Guru selalu berusaha memberi perhatian kepada setiap siswa secara merata, memberikan umpan balik yang sifatnya "segera" terhadap jawaban ataupun pertanyaan siswa. Umpan balik dilakukan dengan cara yang bervariasi yaitu melalui ucapan/kata-kata verbal, sanjungan, anggukan, dan acungan jempol.

7) Interarksi antar Siswa

Dalam pembelajaran siklus III ini tampak adanya interaksi antar kelompok dalam mengerjakan tugas. Hampir semua siswa aktif, perhatian guru terhadap siswa merata, guru juga sering berkeliling kelas untuk memberikan bimbingan dan pengarahan sehingga secara tidak langsung siswa lebih berpikir kritis, aktif, konstruktif, dan tertib sampai waktu pembelajaran berakhir.

\section{b. Keaktifan Siswa dalam Kelompok}

1). Semua siswa terlibat dalam pembelajaran, yakni dengan menunjukkan kesungguhannya dalam belajar.

2). Hampir semua siswa aktif dalam kelompoknya.

3). Semua siswa aktif dalam melaksanakan tugas yang diberikan guru bersama teman-teman dalam kelompoknya.

4). Keberanian setiap siswa dalam menyampaikan hasil tugas kelompoknya sudah mencapai $100 \%$, adanya monopoli pun sudah tidak terlihat lagi.

5). Kerjasama dalam kelompok terjalin dengan baik terlihat dengan adanya kekompakan dalam kerja kelompok

6). Semua siswa sudah menunjukkan antusiasmenya dalam pembelajaran.

\section{c. Hasil Pembelajaran}

1) Secara prosentase keterampilan mendeskripsi secara tertulis siswa kelas II pada tindakan siklus III mengalami peningkatan yaitu $86,3 \%$.

2) Dari 22 siswa yang memiliki keterampilan mendeskripsi secara tertulis dengan sangat baik ada 2 siswa (32\%), memiliki keterampilan baik ada 12 siswa (54\%), berketerampilan sedang ada 9 siswa (14\%).

3) Secara umum hampir semua siswa sudah terampil dalam mendeskripsi secara tertulis.

4) Hampir semua siswa terampil dalam menulis dengan menggunakan pilihan kata yang tepat dan tulisan yang rapi. 
Melalui pembelajaran kontekstual dengan mendayagunakan gambar seri yang berhubungan dengan binatang yang dijadikan sebagai objek dapat meningkatkan keterampilan siswa dalam mendeskripsi secara tertulis, semangat siswa, daya imajinasi siswa dan partisipasi aktif siswa dalam kelompok dan antar siswa di dalam proses pembelajaran.

\section{d. Analisis dan Refleksi Tindakan III 1) Proses Pembelajaran}

Jalannya pelaksanaan siklus III ini mulai dari perencanaan sampai pemberian tindakan dan evaluasi akhir telah lancar dan lebih baik dari siklus I dan siklus II. Hal ini disebabkan karena adanya perbaikan-perbaikan berdasarkan kekurangan ataupun kelemahan pada siklus sebelumnya.

Aktivitas guru mupun aktivitas siswa sedikit demi sedikit mengalami peningkatan. Hal ini terbukti dari hasil observasi terhadap kegiatan siswa oleh guru dan kegiatan guru oleh observer yang menunjukkan kecenderungan meningkat.

Keberanian siswa untuk bertanya dan menjawab pertanyaan serta mengungkapkan pendapat ataupun mengungkapkan hasil kerja kelompok semakin baik pula. Hal ini dapat dilihat dari siswa yang biasanya diam atau pasif, sekarang berani bertanya bahkan berani menyampaikan hasil kerja kelompoknya.

Semangat atau antusias, perhatian, dan partisipasi aktif siswa dalam pembelajaran keterampilan mendeskripsi secara tertulis terlihat jelas yang berpengaruh pada meningkatnya keterampilan siswa dalam mendeskripsi binatang secara tertulis.

\section{2) Hasil Pembelajaran}

Prosentase hasil kemampuan mandeskripsi secara tertulis pada siklus III adalah sebesar 86,3\%, sedangkan prosentase hasil pembelajaran pada siklus II adalah sebesar $59 \%$. Hal ini berarti ada peningkatan hasil keterampilan mendeskripsi secara tertulis pada siklus III sebesar $27,3 \%$ yakni dari kategori sedang menjadi kategori sangat baik.

Hasil studi pendahuluan dalam penelitian tindakan ini dari 22 jumlah siswa kelas II tahun pelajaran 2015/2016 SDN Punik Lombok Tengah yang mampu mendeskripsi secara tertulis dengan baik dan memperoleh nilai di atas 70 (nilai KKM menulis) ada 6 siswa atau hanya $27 \%$. Dari hasil prosentase yang sangat kurng inilah maka diadakan atau ditindaklanjuti dengan usaha-usaha perbaikan pembelajaran yaitu dengan melaksanakan tindakan atau siklus I, melalui pembelajaran kontekstual dengan mendayagunakan gambar binatang sebagai media utama dalam pelaksanaan siklus.
Dari hasil pelaksanaan pembelajaran pada siklus I secara prosentase kemampuan/keterampilan mendeskripsi secara tertulis terjadi peningkatan yang cukup signifikan yakni sebesar $18,4 \%$, atau tepatnya sebelum dilaksanakan tindakan prosentase yang dicapai sebesar $27 \%$ meningkat menjadi $45,4 \%$ setelah dilaksanakan siklus I.

Berdasarkan hasil observasi dan analisis, meskipun siklus I ini terjadi peningkatan hasil keterampilan mendeskripsi secara tertulis namun masih dalam kategori kurang. Hal ini dapat dilihat karena dari sebagian besar siswa masih belum bisa menulis dengan baik, karena pilihan kata yang digunakan belum tepat. Selain itu tulisan yang disajikan juga belum terlihat rapi dan cenderung acak-acakan sehingga sukar dibaca. Adapun cara mengatasi masalah ini, guru menggunakan pembelajaran kontekstual dengan mendayagunakan media gambar binatang dalam hal ini sapi sebagai alternatif pembelajaran. Gambar sapi dipilih sebagai media karena binatang tersebut sudah dikenal baik oleh siswa sehingga tidak terlalu sulit bagi siswa untuk mendeskripsikannya.

Tindakan II atau siklus II lebih berhasil dibanding dengan tindakan/siklus I dengan hasil prosentase $59 \%$ dalam kategori sedang, sedangkan hasil prosentase tindakan I adalah 45,4\%. Hal ini berarti ada peningkatan hasil sebesar $13,6 \%$. Peningkatan hasil pada siklus II ini disebabkan karena guru lebih kreatif dan imajinatif yakni dengan menggunakan puzzle (potongan gambar). Dampak ataupun hasil dari penggunaan media tersebut sangat positif, sebab siswa jadi tertarik dan responsif serta gembira dalam belajar. Dengan perasaan yang senang maka bukan tidak mungkin jika hasil pembelajaran pun akan meningkat karena dengan rasa senang maka siswa akan lebih mudah berpikir dan menuliskan apa yang dipikirkannya sesuai dengan gambar yang telah tersusun dengan baik.

Selain dengan media pembelajaran yang lebih variatif, dengan metode kelompok belajar juga memudahkan siswa untuk mendeskripsi dengan baik. Hal itu karena dengan berkelompok, siswa lebih mudah untuk bertukar pikiran dan menambah pengetahuan tentang objek yang akan dideskripsikan, sehingga siswa dapat menulis dengan baik. Dengan kelompok belajar dapat meningkatkan sikap bersahabat dan kepedulian siswa terhadap teman-temannya.

Keberhasilan tindakan pada siklus II ini belum bisa dikatakan berhasil dengan baik karena hasil pembelajarannya baru mencapai kategori sedang dengan prosentase sebesar 59\%. Oleh karena itu peneliti (guru) masih harus melaksanakan tindakan pada siklus berikutnya untuk mencapai hasil yang maksimal dan optimal.

Pada pelaksanaan tindakan III atau siklus III kegiatan pembelajaran yang dilaksanakan adalah mendeskripsi binatang secara tertulis dan membuat kalimat tebak-tebakan tentang seekor binatang melalui 
urutan gambar seri. Dengan bantuan gambar seri tersebut, siswa dapat mendeskripsi binatang dengan baik yakni dengan meyebutkan hal-hal yang berhubungan dengan binatang tersebut. Selain itu siswa dapat membuat kalimat tebak-tebakan dengan pilihan kata yang tepat. Sehingga pada siklus III pembelajaran dianggap berhasil dan tujuan pembelajaran tercapai.

Dengan strategi pembelajaran dan penggunaan media pembelajaran yang lebih kompleks dan menarik pada pelaksanaan proses pembelajaran siklus III ini seluruh sswa berpartisipasi aktif dan antusiasme siswa pada kegiatan tersebut dan kerjasama antar siswa siswa juga meningkat. Oleh karena itu dampak yang ditimbulkan terhadap pembelajaran yang berbasis kontekstual dengan mendayagunakan media gambar, dalam hal ini gambar seri sangat positif. Hal itu berpengaruh pada penacapaian hasil belajar siswa pada keterampilan mendeskripsi secara tertulis pada siklus III ini mengalami peningkatan. Secara prosentase hasil kemampuan siswa pada siklus III ini adalah $86,3 \%$ atau dalam kategori sangat baik, sedang prosentase hasil siklus sebelumnya atau siklus II adalah 59\% sehingga ada peningkatan sebesar $27,3 \%$.

Dengan demikian penelitian tindakan kelas dengan mengambil mata pelajaran Bahasa Indonesia pada pembelajaran mendeskripsi secara tertulis melalui penerapan pembelajaran kontekstual dengan memanfaatkan gambar binatang sebagai media utama dalam pembelajaran berhasil sesuai dengan harapan yaitu dapat meningkatkan prestasi belajar siswa khususnya meningkatkan keterampilan mendeskripsi secara tertulis pada siswa kelas II SDN Punik Lombok Tengah.

\section{SIMPULAN DAN SARAN}

Berdasarkan hasil penelitian tentang penerapan pembelajaran kontekstual untuk meningkatkan keterampilan mendeskripsi secara tertulis pada siswa kelas II SDN Punik Lombok Tengah dapat disimpulkan sebagai berikut:

1. Kegiatan pembelajaran mendeskripsi secara tertulis pada sisiwa kelas II SD dilaksanakan berdasarkan aspek-aspek kemampuan/keterampilan yang harus dimiliki oleh siswa sesuai indikator-indikator berikut:

a). Siswa dapat mendeskripsi secara tertulis dengan pilihan kata yang tepat.

b). Siswa dapat menyajikan tulisan dengan bentuk tulisan yang rapi.

c). Siswa dapat mendeskripsi binatang dalam bentuk kalimat tebak-tabakan.

2. Proses pelaksanaan pembelajaran mendeskripsi secara tertulis melalui penerapan pembelajaran kontekstual dengan memanfaatkan media gambar binatang dapat meningkatkan keterampilan mendeskripsi secara tertulis siswa kelas II SDN Punik Lombok Tengah.
Peningkatan keterampilan mendeskripsi secara tertulis ini dapat dilihat dari hasil pelaksanaan penelitian yaitu prosentase pada studi pendahuluan sebesar $27 \%$, atau hanya 6 siswa dari 22 siswa yang mampu menulis dengan baik yakni dapat mencapai nilai di atas nilai 70 atau nilai KKM pada aspek menulis. Hasil siklus I meningkat menjadi 45,4\% (kurang) karena dari 22 siswa 10 siswa yang berhasil memperoleh nilai di ats nilai KKM, hasil pelaksanaan siklus II meningkat sebesar 59\%(sedang) yakni dari 22 siswa 13 siswa berhasil memperoleh nilai di atas nilai KKM, dan pada siklus III mengalami peningkatan sebesar $86,3 \%$ (sangat baik), dari 22 siswa yang dijadikan sampel ada 7 siswa dalam kategori sangat baik dan 12 siswa dalam kategori baik.

3. Proses pembelajaran mendeskripsi secara tertulis melalui penerapan pembelajaran kontekstual dengan memnfaatkan media gambar binatang yang cukup bervariasi dapat meningkatkan motivasi belajar, dan partisipasi aktif siswa. Hal ini dapat dilihat dari kerja sama antar siswa yang semakin meningkat, antusiasme siswa dalam belajar, kesungguhan siswa dalam mengerjakan tugas sekaligus mempresentasikan hasil kerjanya juga meningkat, siswa terlihat tertib dan gembira untuk selalu mengikuti pembelajaran dari awal sampai akhir pembelajaran.

4. Penggunaan pendekatan kontekstual oleh guru dalam pembelajaran juga meningkatkan keterampilan guru dalam pembelajaran. Dengan meng-gunakan pendekatan kontekstual guru jadi lebih responsif terhadap siswa, karena dengan adanya kelompok belajar mau tidak mau guru harus memberikan bimbingan terhadap setiap kelompok sehingga diskusi dalam kelompok lebih hidup dan tidak pasif. Selain itu, guru juga lebih aktif dan kreatif dalam memotivasi siswa dalam belajar, sehingga siswa lebih respon terhadap pembelajaran yang sedang berlangsung.

5. Kesalahan-kesalahan yang sering dilakukan siswa dalam mendeskripsi secara tertulis adalah meliputi kesalahan penggunaan atau pemilihan kata yang tepat dalam menggambarkan seekor binatang dengan baik sehingga cenderung berulang-ulang. Akan tetapi kesalahankesalahan tersebut dapat di atasi dengan pembelajaran berbasis kontekstual yang memanfaatkan media gambar binatang sebagai media alternatif dalam pembelajaran mendeskripsi secara tertulis siswa kelas II.

Setelah dilakukan penelitian di SDN Punik Lombok Tengah dan berdasarkan hasil yang diperoleh di lapangan, maka diajukan saran kepada pihak yang 
berkaitan dengan masalah ini dalam hal ini pembaca, adalah sebagai berikut:

1. Bagi guru, dalam pembelajaran menulis khususnya menulis deskripsi diupayakan untuk menggunakan media baik berupa gambar ataupun model nyata sehingga memperpudah siswa untuk mendeskripsi objek dengan baik.

2. Bagi pihak-pihak lain yang ingin meneliti lebih lanjut, disarankan untuk mengembangkan penerapan pembelajaran kontekstual dengan mendayagunakan media gambar dalam hal ini gambar binatang yang lebih kreatif dan bervariasi, sehingga lebih menarik minat siswa dalam kegiatan pembelajaran.

3. Bagi Pengawas TK-SD, Kepala Sekolah, Instansi atau praktisi pendidikan perlu mendiskusikan, mengimplementasikan dan menindaklanjuti strategi pembelajaran kontekstual dengan media gambar yang bervariasi pada setiap pembelajaran menulis khususnya dalam mendeksripsi secara tertulis pada siswa kelas III, IV, V, dan VI SD.

\section{UCAPAN TERIMA KASIH}

Dengan penuh rasa hormat, saya ucapkan teimakasih kepada:

Kepala Dinas Pendidikan yang telah memfasilitasi, mengizinkan penulis untk mengadakan penelitian hingga dapat terlaksana dengan baik.

Ketua PGRI Kabupaten Lombok Tengah yang turut memotivasi untuk terlaksananya penelitian di sekolah secara reguler.

Guru-guru yang telah memberi dukungan baik secara moral maupun tindakan langsung dalam pelaksanaan penelitian ini.

\section{DAFTAR RUJUKAN}

[1] Alfianto, Achmad. 2006. Pelajaran Bahasa Indonesia di Sekolah, Metamorfosis Ulat menjadi Kepompong. Artikel Pendidikan Network. Online http://reresearchengines.com, [accessed 24/10/07].

[2] Anagram. 2007. Pentingnya Bahasa dalam Kehidupan. Online http://reinemarie.wordpress.com [accessed 27/04/08].

[3] Ani, Diah. 2007. Pembelajaran Pakem. Sebuah Perjalanan Menuju Perubahan. Online http://mbeproject.net [accessed 15/01/o8].

[4] Aqib, Zainal. 2006. Penelitian Tindakan Kelas untuk Guru. Bandung: Yrama Widya.

[5] Arya Yanti, P. 2007. Menumbuhkan Budaya Menulis pada Anak. Online http://www.sabda.org [accessed 24/02/08].

[6] BSNP, 2006. Standar Kompetensi dan Kompetensi Dasar $S D / M I$. Jakarta : Badan Standar Nasional Pendidikan.

[7] Darsono, Max, 2000. Belajar dan Pembelajaran. Semarang: IKIP Semarang Press.

[8] Depdikbud, 1994. Kurikulum SD GBPP Bahasa Indonesia. Jakarta: Depdikbud.
[9] Depdiknas, 2007. Pembelajaran Aktif Kreatif, Efektif dan Menyenangkan. Online http://farhanzen.wordpress.com [accessed 15/01/o8].

[10] Dikdasmen Diknas, 2002. Pendekatan Kontekstual (Contextual Teaching and Learning (CTL)). Jakarta: Depdiknas.

[11] Hamidi, Z. 2001. P\&P Kontekstual Sains dan Tematik, Online http://www.tutor.com.my [accessed 22/11/07].

[12] Johnson, Elaine B, 2008. Contextual Teching \& Learning. Bandung: Mizan Learning Center (MLC)

[13] Kusumah, W. 2007. Media Pembelajaran. Online http://wijayalabs.blogspot.com [accessed 10/03/o8].

[14] Mastur, Zaenuri. 2004. Model Pembelajaran Lingkungan. Online http://www.suaramerdeka.com [accessed 06/11/07]

[15] .Muchith, M. Saekhan, 2008. Pembelajaran Kontekstual. Semarang: RaSAIL Media Group.

[16] Pantow, Johana, dkk. 2002. Analisa kemampuan menulis Bahasa Inggris Mahasiswa FKIP-UT. Online http://digilib.itb.ac.id [accessed 26/01/o8].

[17] PTK, 2008. Salah Satu Contoh PTK dalam Bidang Bahasa. Online http://aflahchintya23.wordpress.com [accessed 10/03/08].

[18] Purwaningtyas, Sri. 2007. Pengaruh Pendekatan Kontekstual (CTL) Terhadap Keterampilan Menulis Deskripsi. Online http://pasca.uns.ac.id, [accssed 10/03/08].

[19] Purwanto, M. Ngalim. 1997. Metodologi Pengajaran Bahasa Indonesia di Sekolah Dasar. Jakarta: Rosda Jayaputra.

[20]Pustaka, Pepak. 2002. Aktivitas Menulis. Online http://pepak.sabda.org, [accessed 10/03/o8].

[21] Sadulloh, Uyoh. 2003. Pengantar Filsafat Pendidikan. Bandung: Alfabeta.

[22] Sriwilujeng, Dyah, dkk. 2007. Pembelajaran Terpadu dengan Pendekatan Tematik. Malang: Erlangga.

[23] Sukmana. 2004. Dinamika Proses Belajar. Online http://www.pikiran-rakyat.com, [accessed 15/01/o8].

[24] Syaharudin, D. 2007. Penggunaan Media Gambar untuk Meningkatkan Keterampilan Menulis Karangan Prosa. Online http://ind.sps.upi.edu, [accessed 10/03/o8].

[25] Wibowo, M.E. 2006. Panduan Menulis Karya Ilmiah. Semarang. Universitas Negeri Semarang.

[26] Wijayanti, Ari. 2007. Pengajaran Bahasa Indonesia yang Efektif. Portal Dunia Guru. Online http://lubisgrafura.wordpress.com [accessed 24/10/07].

[27] Wikipedia Indonesia. 2006. Menulis. Online http://id.wikipedia.org, [accessed 15/01/o8]. 